\title{
FAKTOR-FAKTOR MEMPENGARUHI HARGA SAHAM TERHADAP PERUSAHAAN TRANSPORTASI DAN LOGISTIK BURSA EFEK INDONESIA
}

\author{
Eky Kriswahyuni ${ }^{1}$, Syahril Effendi ${ }^{2}$ \\ Universitas Putera Batam \\ pb160810220@upbatam.ac.id
}

\begin{abstract}
Transportation and logistics companies are sectors of companies that are affected by the presence of Covid-19.The purpose of this study was to determine the ratio of financial analysis with liquidity, activity, profitability and solvency partially and simultaneously on stock prices in the transportation and logistics sectors. The method used in this research is secondary data analysis of the financial statements of transportation and logistics companies listed on the IDX from 2015-2019 which are quantitative with a population of 60, the number of samples is 11 using non-probability purposive sampling type so that 55 data reports finance. The results of the study partially show that the liquidity value has no effect on stock prices, activity affects stock prices with a value of, profitability affects stock prices with a value of, solvency has no effect on stock prices with a value of. Simultaneously (simultaneously) Liquidity, Activity, Profitability, Solvency on share prices.
\end{abstract}

Keywords: Liquidity; Activity; Profitability; Solvency; Price;

\section{PENDAHULUAN}

Saat ini, pandemi yang baru saja melanda seluruh negara berada dalam keadaan yang sangat menggemparkan, yakni Coronavirus 2019 (COVID-19) yang pertama kali terdeteksi di Wuhan, China pada akhir musim 2019 lalu. Hampir setiap negara mengambil kebijakan yang sama Agar tidak menyebar atau memutuskan rantai virus tersebut sementara di Indonesia Desember lalu dan pemerintah merancang kebijakan lockdown (kunci akses). Kontrol penyebaran virus (dengan dan dari negara), memang tidak dapat dipungkiri bahwasanya dalam bersosialisasi setiap negara saling membutuhkan satu dengan yang lainnya termasuk dalam konteks perekonomian, Menurut situasi pasar ini, pertumbuhan mikro dan makro di semua mengalami mikromacriets di semua bidang, termasuk perusahaan transportasi dan logistik pada Bursa Efek Indonesia (BEI).

Perusahaan transportasi dan logistik merupakan sektor perusahaan yang terdampak dengan adanya covid-19 ini sebab perusahaan-perusahaan tersebut merupakan perusahaan garda terdepan yang berhubungan dengan negara lain.

Menteri Perhubungan (MENHUB) Karya Sumadi dalam media Berita Satu juga menyatakan bahwa sektor transportasi dan logistik terpukul paling parah oleh Covid-19 dimana omzetnya mengalami penurunan lebih $30 \%$ dan pendapatan penerbangan mengalami penurunan lebih dari $50 \%$ bahkan penurunan ini menyebabkan pertumbuhan ekonomi Indonesia terkoreksi minus 5,32\%. Asosiasi Pengusaha Truk Indonesia (APTRINDO) dalam media Kontan.co.id juga menyatakan bahwa omzet dari perusahaan logistik mengalami penurunan hingga $90 \%$ padahal sebelumnya sebelum pandemi dapat tumbuh hingga 15,2\%.

Selain terjadinya penurunan omzet dan pendapatan yang dialami oleh perusahaan sektor transportasi dan logistik tentunya juga dapat berdampak pada rasio keuangannya dan juga harga sahamnya yang diperdagangkan di BEI sebab apabila omzet dan pendapatan perusahaan menurun tentunya perusahaan tidak dapat membagikan dividen pada setiap investor dan juga 
tentunya investor akan cenderung menarik sahamnya pada perusahaan hal ini dapat menurunkan harga saham pada akhirnya.

Rasio keuangan merupakan metode analisa kinerja keuangan suatu perusahaan yang digunakan oleh investor untuk memilih saham perusahaan. Rasio keuangan dan harga saham ini memiliki hubungan erat dengan omzet dan pendapatan yang dialami perusahaan.

Berikut ini merupakan pertumbuhan harga saham Perusahaan Sektor Transportasi Dan Logistik:

Tabel 1. Pertumbuhan Harga Saham Perusahaan Sektor Transportasi Dan Logistik

\begin{tabular}{llrrr}
\hline KODE & \multicolumn{1}{c}{ NAMA PT } & \multicolumn{3}{c}{ HARGA CLOSING } \\
SAHAM & & $\mathbf{2 0 1 9}$ & $\mathbf{2 0 2 0}$ & PERTUMBUHAN \\
\hline AKSI & Maming Enam Sembilan Mineral & 1145 & 414 & $-177 \%$ \\
ASSA & Adi Sarana Armada & 740 & 635 & $-17 \%$ \\
BIRD & Blue Bird & 2490 & 1300 & $-92 \%$ \\
BLTA & Berlian Laju Tanker & 50 & 50 & $0 \%$ \\
BPTR & Batavia Prosperindo Trans & 89 & 81 & $-10 \%$ \\
DEAL & Dewata Freightinternational & 180 & 142 & $-27 \%$ \\
GIAA & Garuda Indonesia (Persero) & 498 & 402 & $-24 \%$ \\
HELI & Jaya Trishindo & 210 & 216 & $3 \%$ \\
IATA & Indonesia Transport \& Infrastr & 50 & 50 & $0 \%$ \\
JAYA & Armada Berjaya Trans & 83 & 128 & $35 \%$ \\
KJEN & Krida Jaringan Nusantara & 2060 & 1145 & $-80 \%$ \\
LRNA & Eka Sari Lorena Transport & 131 & 200 & $35 \%$ \\
MIRA & Mitra International Resources & 50 & 50 & $0 \%$ \\
NELY & Pelayaran Nelly Dwi Putri & 141 & 142 & $1 \%$ \\
SAFE & Steady Safe & 206 & 188 & $-10 \%$ \\
SAPX & Satria Antaran Prima & 830 & 2190 & $62 \%$ \\
SDMU & Sidomulyo Selaras & 50 & 50 & $0 \%$ \\
SMDR & Samudera Indonesia & 254 & 284 & $11 \%$ \\
TAXI & Express Transindo Utama & 50 & 50 & $0 \%$ \\
TMAS & Temas & 102 & 138 & $26 \%$ \\
TNCA & Trimuda Nuansa Citra & 278 & 424 & $34 \%$ \\
TRUK & Guna Timur Raya & 101 & 171 & $41 \%$ \\
WEHA & WEHA Transportasi Indonesia & 148 & 63 & $-135 \%$ \\
\multicolumn{1}{c}{ Rata-Rata Pertumbuhan } & & & $-14 \%$ \\
\hline
\end{tabular}

(Sumber : BEl dan Diolah Peneliti 2021)

Data yang diperoleh ini merupakan harga saham pada saat closing Desember 2019 dan Desember 2020 dimana pandemi terjadi antara tahun tersebut. Dari data BEI dan diolah peneliti ditemuan bahwasanya memang terjadi penurunan pertumbuhan harga saham selama pandemi covid-19 ini yakni sebesar -14\% dimana yang paling berkontribusi terhadap penurunan harga saham ini adalah PT. Weha Transportasi Indonesia Tbk (WEHA) sebesar -135\% dan disusul dengan saham PT. Maming Enam Sembilan Mineral (AKSI) sebesar -177\%.

Faktor penentu naik dan turunnya harga saham perusahaan dalam pasar modal adalah banyaknya transaksi jual beli yang terjadi, apabila sebuah saham perusahaan sangat diminati dan dibeli sahamnya oleh investor maka saham perusahaan tersebut dapat terjadi kenaikan yang dialaminya begitu juga dengan keadaann yang sebaliknya apabila seorang investor mulai tidak tertatik dan tidak minat bahkan menjual sahamnya kepemilikannya di perusahaan maka harga saham juga dapat mengalami down (penurunan).

Kenaikan harga saham umumnya searah dengan hasil kinerja keuangan perusahaan dengan istilah lainnya kenaikan laba atau pendapatan. Keyakinan terhadap keadaan kinerja keuangan perusahaan menjadikan indikator atau dasar berniat atau tidaknya investor pada saham perusahaan.

Kunci utama investor dalam memilih saham adalah memperhatikan faktor fundamental dari kinerja keuangan perusahaan itu sendiri sebelum menentukan investasinya dalam sebuah saham perusahaan, andaipun demikian kadangkala terjadi juga penurunan harga saham perusahaan sekalipun kinerja keuangan perusahaan tadi baik hal ini mampu ditimbulkan lantaran keadaan pasar yangg sedang memburuk (bearsh) sebagai akibatnya menciptakan sigma investor terguncang. 
Hal terpenting dalam berinvestasi saham adalah harga sahamnya, dan investor harus mewaspadai hal ini. Dalam beberapa penelitian yangtelah dianalisis dan dilakukan oleh banyak orang, harga saham sangat erat kaitannya dengan kinerja keuangan. umumnya digunakan metode analisis dengan rasio. Indeks rasio tersebut mengukur kinerja keuangan perusahaan dengan menganalisis indikator perdagangan (termasuk indeks likuiditas, aktivitas, profitabilitas, dan solvabilitas), yang dapat memengaruhi harga saham.

Likuiditas merupakan analisis yang dijadikan investor guna melihat kemampuan perusahaan (emiten) untuk melunasi kewajibannya secara jangka pendek dalam jangka waktu tertentu (Syahyunan, 2015), tentunya investor memperhatikan rasio ini sebagai analisisnya untuk melihat kemampuan perusahaan sebab likuiditas menjadi salah satu faktor penentu berkembang atau tidaknya perusahaan yang dilihat dari pengelolaan hutang yang dimiliki atau kewajibannya.

Tentunya dibandingkan dengan periode sebelumnya, tingkat likuiditas perusahaan yang lebih tinggi, yang mungkin menjadi kabar baik bagi investor investasi, dan pada akhirnya meningkatkan kepercayaan investor terhadap perusahaan sehingga investor dapat membeli saham dan harga saham. Hal ini juga akan berpengaruh, sebaliknya jika tingkat likuiditas turun, investor akan ragu dan ragu untuk membeli saham perusahaan karena diasumsikan tidak dapat mengelola hutangnya. Teori dalam signaling telah menyatakan bahwa likuiditas perusahaan yang semakin meningkat merupakan sinyal baik yang diberikan untuk investor dalam berinvestasi. Akibatnya indeks likuiditas sangat erat kaitannya dengan perubahan harga saham. Teori dan pernyataan tersebut didukung oleh penelitian sebelumnya (Idamanti, 2018) yang berarti bahwa likuiditas yang diukur dengan menggunakan indikator saat ini memiliki pengaruh yang signifikan terhadap harga saham.

Selain itu, data kunci lainnya seperti rasio aktivitas merupakan salah satu jenis metrik yang digunakan dalam studi kelayakan untuk mendorong investor mengambil keputusan membeli saham perusahaan, karena metrik aktivitas ini merupakan analisis yang digunakan untuk mengevaluasi kelayakan suatu perusahaan. investasi. Jika tingkat aktivitas suatu perusahaan diasumsikan meningkat, maka hal ini tentunya juga menjadi sinyal bagi investor untuk membeli saham guna menaikkan harga saham.

Rasio profitabilitas sebagai analisis kinerja keuangan perusahaan juga sering dikaitkan oleh bayak investor terhadap pergerakan saham. Untuk mengukur dan memprediksi keefektivitasan perusahaan dalam menghasilkan keuntungan maka digunakanlah rasio profitabilitas. Kebijakan perusahaan dalam membagikan dividen kepada pemegang saham tercermin dari profitabilitas yang dicapai dan juga dapat dianalisis berdasarkan kinerja keuangan dalam bentuk laporan keuangan. Nilai positif dari profitabilitas perusahaan akan mencerminkan jumlah dividen yang akan dibagikan. Jika profitabilitas tinggi tentunya perusahaan mempu membayar dividen besar untuk investor, hal ini akan membuat investor tertarik pada perusahaan yang memiliki profitabilitas baik sehingga harga saham juga akan meningkat.

Rasio solvabilitas merupakan indikator faktor-faktor yang mendorong harga saham karena indeks merupakan analisis yang digunakan untuk menilai sejauh mana aset suatu perusahaan dibiayai oleh hutang. Investor apabila dipandang secara jangka panjang tentunya menginginkan perusahaan pilihannya untuk terus aktif sehingga memperoleh keuntungan, maka investor sebelum memilih saham akan memperhatikan salah satu rasio solvabilitas tersebut. Investor akan memilih saham dengan melihat solvabilitasnya dan akan membelinya jika memiliki solvabilitas atau resiko rugi yang rendah, oleh sebab itu maka rasio ini dapat mempengaruhi pergerakan saham.

\section{TINJAUAN PUSTAKA}

\subsection{Harga Saham}

Harga saham adalah nilai nominal internal yang diumumkan dari saham perusahaan yang diperdagangkan. Jika perdagangan mewakili nilai intrinsik aset, kapasitas produksi di 
masa depan, dan kondisi bisnis, maka harga biasanya didasarkan pada dampak penawaran dan permintaan pasar modal, dan dampak ini menentukan bentuk harga pertama..

Menurut anoraga dalam (Nisa, 2018) adalah nilai arus kas saat ini yang akan diterima pemilik di masa depan. Variabel transaksi ini menggunakan harga saham sebagai harga pasar akhir tahun / akhir tahun.

\subsection{Likuiditas}

Likuiditas merupakan analisis yang dijadikan investor guna melihat kemampuan perusahaan (emiten) untuk melunasi kewajibannya secara jangka pendek dalam jangka waktu tertentu (Syahyunan, 2015). Jenis rasio (metrik) ini merupakan metrik yang menentukan kapabilitas perusahaan dengan membandingkan aset lancar perusahaan dengan kewajiban hutang lancar. Dapat dikatakan bahwa rasio ini mengukur tingkat keamanan perusahaan saat menerbitkan invoice berdasarkan waktu.

Dalam operasional variabel ini peneliti menggunakan rasio lancar sebab dalam penelitian penelitian terdahulu juga telah banyak digunakan rasio lancar (Current Ratio). Rumus berikut digunakan untuk menghitung rasio:

$$
\text { Current Ratio }=\frac{\text { Aktiva Lancar }}{\text { Utang Lancar }}
$$

\section{Rumus 1. Rasio lancar (Current Ratio)}

\subsection{Aktivitas}

Menurut (Kasmir, 2016) Indeks tersebut digunakan untuk mengukur dampak perusahaan terhadap pengelolaan aset yang ada. Dapat dikatakan juga Bagian ini adalah ukuran kemampuan perusahaan untuk menggunakan sumber daya yang tersedia demi menghasilkan keuntungan.

Rasio aktivitas juga merupakan salah satu dari jenis rasio yang digunakan dalam menganalisis kelayakan investasi bagi investor untuk penentuan membeli saham perusahaan. Sebab rasio aktivitas ini merupakan analisis yang digunakan untuk melihat kemampuan dan keefektifan perusahaan dalam mengelola asset yang dimilikinya untuk mendukung kegiatan operasional perusahaan dalam menghasilkan pendapatan atau keuntungan dalam satu periode (Syahyunan, 2015)

Semakin tinggi analisis rasio aktivitas pada perusahaan yang dihasilkan dari penggunakan asset maka harga saham juga akan meningkat karena rasio ini menilai tentang perputaran kecepatan asset sehingga mampu menghasilkan laba. Investor umumnya berharap imbal hasil investasi dari saham yang biasanya disebut dividen, dividen tersebut diperoleh dari pendapatan bersih perusahaan yang akan dibagikan pada setiap pemegang saham oleh karena itu investor yang berharap dari dividen tuntunya akan memperhatikan analisis rasio aktivitas ini. Jika tingkat aktivitas suatu perusahaan diasumsikan meningkat, maka hal ini tentunya juga menjadi sinyal bagi investor untuk membeli saham guna menaikkan harga saham.

Perbandingan ini dapat diukur dengan menggunakan rumus berikut:

$$
\text { TATO }=\frac{\text { Penjualan }}{\text { Total Aktiva }}
$$

\section{Rumus 2. Perputaran Total Aktiva (Total Assets Turn Over)}

\subsection{Profitabilitas}

Menurut (Sudana, 2011) Profitabilitas merupakan salah satu alat analisis keuangan perusahaan, memungkinkan setiap investor untuk melihat persentase perusahaan yang dapat 
memperoleh pendapatan atau keuntungan paling banyak darinya. Rasio profitabilitas sebagai analisis kinerja keuangan perusahaan juga sering dikaitkan oleh bayak investor terhadap pergerakan saham. Nilai positif dari profitabilitas perusahaan akan mencerminkan jumlah dividen yang akan dibagikan. Jika profitabilitas tinggi tentunya perusahaan mempu membayar dividen besar untuk investor, hal ini akan membuat investor tertarik pada perusahaan yang memiliki profitabilitas baik sehingga harga saham juga akan meningkat. Kecenderungan akan naiknya harga saham ditentukan dari banyaknya orang yang melakukan pembelian dan begitu juga sebaiknya akan mengalami penurunan apabila banyak penjualan.

Untuk mengukur rasi ini digunakan rumus :

$$
\text { Profit Margin }=\frac{\text { Penjualan Bersih }-H P P}{\text { Penjualan }}
$$

\section{Rumus 3. Gross Profit Margin (GPM)}

\subsection{Solvabilitas}

Solvabilitas merupakan bagian yang mengukur kemampuan perusahaan dalam membayar debitur sebagai pemberi pinjaman dalam jangka pendek dan panjang. Jenis rasio yang digunakan adalah Debt to Equity Ratio (DER). Rasio ini digunakan untuk mengetahui hubungan antara total kewajiban dengan modal atau saldo perusahaan. Jika hutang lebih besar dari pada modal maka ini merupakan nilai yang buruk sebab kemungkinan besar apabila perusahaan mengalami likuiditas maka dapat dikatakan perusahaan tidak mampu membayar hutang nya sekalipun modal ekuitas digunakan. Untuk menilai rasio ini maka digunakan rumus sebagai berikut :

$$
\text { Debt to Equity Ratio }=\frac{\text { Total Utang }}{\text { Ekuitas }}
$$

\section{Rumus 4. Debt to Equity Ratio (DER)}

\section{METODE}

Jenis penelitian ini merupakan penelitian kuantitatif serta sumber data dalam penelitian ini merupakan data sekunder dimana peneliti memperoleh data-data untuk dianalisis dari teknik dokumentasi ataupun melihat dan mengunjungi website BEI dan juga sebagai tambahan mengunjungi website yang relevan seperti Lembar saham.com, investing .com dan lain sebagainya. teknik dalam pengumpulan data adalah melalui observasi literatur.

Dalam penelitian ini populasi berjumlah 27 perusahaan yang terdaftar di Bursa Efek Indonesia (BEI) sektor Transportasi dan Logistik. Dan Jumlah sampel dalam penelitian ini adalah 11 perusahaan sektor transportasi dan logistik yang tedaftar di BEI. Jenis sampelnya adalah non-probability purposive sampling dengan kriteria:

1. Perusahaan yang terdaftar di BEI selama 5 tahun terakhir yakni tahun 2015-2019.

2. Perusahaan transportasi dan logistik yang rutin menyampaikan laporan keuangan.

3. Perusahaan transportasi dan logistik yang memperoleh nilai rasio tidak pernah minus.

4. Perusahaan transportasi dan logistik yang tidak pernah mengalami delisting atau suspend sampai 1 bulan.

Teknik analisis data dalam penelitian ini terlebih dahulu melakukan analisis pengujian secara asusmsi klasik (uji normalitas, uji multikolenieritas, hiterokedastisitas dan uji atokorelasi). Setelah itu peneliti melakukan pengujian hipotesis secara simultan maupun parsial.

\section{HASIL DAN PEMBAHASAN}

1. Hasil Uji Normalitas 
Uji normalitas merupakan uji sistematis dalam penelitian yang bertujuan untuk mengetahui jumlah data yang berdistribusi normal, karena dalam penelitian yang baik sebaiknya mencari data yang berdistribusi normal. Berikut ini hasil pengujian normalitas :

Tabel 1. Uji Normalitas

\begin{tabular}{llr}
\hline \multicolumn{2}{c}{ One-Sample Kolmogorov-Smirnov Test } \\
\hline \multirow{N}{N}{ Normal Parameters } & \multicolumn{1}{c}{$\begin{array}{c}\text { Unstandardized } \\
\text { Residual }\end{array}$} & 55 \\
& & .0000000 \\
Most Extreme Differences & Sean & Absolute \\
& Positive & .297 \\
& Negative & .297 \\
Test Statistic & & -.239 \\
Asymp. Sig. (2-tailed) & .297 \\
\hline a. Test distribution is Normal. & .640 \\
b. Calculated from data. &
\end{tabular}

Sumber : Output SPSS diolah peneliti (2021)

Dari tabel One-Sample Kolmogorov-Smirnov Test output SPSS diatas menunjukkan nilai Asymp. Sig. (2-tailed) sebesar 0.640 atau > 0.05 (5\%). Dengan demikian dapat dikatakan dalam penelitian tersebut dikatakan data terdistribusi normal.

2. Hasil Uji multikolinearitas

Uji kolinearitas digunakan untuk mengetahui dalam analisis pengujian SPSS apakah terdapat pengujian korelasi antara variabel penjelas, atau untuk menguji apakah tidak terdapat korelasi antara variabel penjelas, atau apakah model data variabel yang baik ditemukan

Tabel 2. Multikolenieritas

\begin{tabular}{|c|c|c|c|c|c|}
\hline \multirow[b]{3}{*}{ Model } & \multicolumn{4}{|c|}{ Coefficients $^{a}$} & \\
\hline & \multicolumn{2}{|c|}{$\begin{array}{l}\text { Unstandardized } \\
\text { Coefficients }\end{array}$} & \multirow{2}{*}{$\begin{array}{c}\text { Standardized } \\
\text { Coefficients } \\
\text { Beta } \\
\end{array}$} & \multicolumn{2}{|c|}{ Collinearity Statistics } \\
\hline & $\mathrm{B}$ & Std. Error & & Tolerance & VIF \\
\hline 1 (Constant) & 4.706 & .574 & & & \\
\hline Likuiditas (X1) & -.579 & .310 & -.409 & .331 & 3.021 \\
\hline Aktivitas (X2) & .635 & .280 & .295 & .940 & 1.064 \\
\hline Profitabilitas (X3) & .343 & .176 & .247 & .997 & 1.003 \\
\hline Solvabilitas (X4) & -.323 & .246 & -.292 & .322 & 3.110 \\
\hline
\end{tabular}

Dari hasil output SPSS untuk pengujian Multikolenieritas pada variabel likuiditas ditemukan nilai VIF $3.021<10$ dan tolerance $0.331>0.100$, pada variabel Aktivitas ditemukan nilai VIF $1.064<10$ dan tolerance $0.940>0.100$, pada variabel profitabilitas ditemukan nilai VIF $1.003<10$ dan tolerance $0.997>0.100$, pada variabel solvabilitas ditemukan nilai VIF $3.110<10$ dan tolerance $0.322>0.100$. dari keseluruhan diatas dapat dikatakan bahwa tidak terjadi multikolinearitas atau korelasi antar variabel dalam penelitian ini.

3. Heteroskedastisitas

Uji heteroskedastisitas digunakan untuk memeriksa apakah penyimpangan antar observasi dalam penelitian model regresi tidak sama. Berikut ini merupakan hasil pengujiannya : 
Tabel 3. Hasil Pengujian Heteroskedastisitas

\begin{tabular}{|c|c|c|c|c|c|c|c|}
\hline & & & Likuiditas & Aktivitas & $\begin{array}{l}\text { Profitabil } \\
\text { itas }\end{array}$ & $\begin{array}{c}\text { Solvabilit } \\
\text { as }\end{array}$ & $\begin{array}{l}\text { Harga } \\
\text { Saham }\end{array}$ \\
\hline $\begin{array}{l}\text { Spear } \\
\text { man's } \\
\text { rho }\end{array}$ & $\begin{array}{l}\text { Likuiditas } \\
\text { Aktivitas } \\
\text { Profitabilit } \\
\text { as } \\
\text { Solvabilit } \\
\text { as } \\
\text { Harga } \\
\text { Saham }\end{array}$ & $\begin{array}{l}\text { Correlation Coefficient } \\
\text { Sig. (2-tailed) } \\
N \\
\text { Correlation Coefficient } \\
\text { Sig. (2-tailed) } \\
N \\
\text { Correlation Coefficient } \\
\text { Sig. (2-tailed) } \\
N \\
\text { Correlation Coefficient } \\
\text { Sig. (2-tailed) } \\
N \text { Correlation Coefficient } \\
\text { Sig. (2-tailed) } \\
\text { N }\end{array}$ & $\begin{array}{r}1.000 \\
55 \\
-.299^{-} \\
.027 \\
55 \\
-.076 \\
.580 \\
55 \\
-.808^{-} \\
.000 \\
55 \\
-.290^{-} \\
.032 \\
55\end{array}$ & $\begin{array}{r}-.299^{-} \\
.027 \\
55 \\
1.000 \\
55 \\
55 \\
-.105 \\
.446 \\
55 \\
.388^{-} \\
.003 \\
55 \\
.444^{-} \\
.001 \\
55\end{array}$ & $\begin{array}{r}-.076 \\
.580 \\
55 \\
-.105 \\
.446 \\
55 \\
1.000 \\
. \\
55 \\
-.052 \\
.704 \\
55 \\
.226 \\
.098 \\
55\end{array}$ & $\begin{array}{r}-.808^{-} \\
.000 \\
55 \\
.388^{-} \\
.003 \\
55 \\
-.052 \\
.704 \\
55 \\
1.000 \\
55 \\
.272^{-} \\
.044 \\
55\end{array}$ & $\begin{array}{r}-.290^{-} \\
.062 \\
55 \\
.444^{-} \\
.110 \\
55 \\
.226 \\
.098 \\
55 \\
.272^{-} \\
.054 \\
55 \\
1.000 \\
55\end{array}$ \\
\hline
\end{tabular}

Dari tabel output diatas dapat disimpulkan bahwa tidak terjadi gejala heteroskedastisitas pada variabel penelitian tersebut karena seluruh variabel mendapatkan nilai Sig. (2-tailed) atau probabilitas $>5 \%$ atau 0.05 .

4. Autokorelasi

Tabel 4. Hasil Heteroskedastisitas/Tes Lagrage Multiplier

\begin{tabular}{|c|c|c|c|c|}
\hline \multicolumn{5}{|c|}{ Model Summary } \\
\hline Model & $\mathrm{R}$ & R Square & $\begin{array}{l}\text { Adjusted R } \\
\text { Square }\end{array}$ & $\begin{array}{l}\text { Std. Error of the } \\
\text { Estimate }\end{array}$ \\
\hline 1 & $.714^{3}$ & .509 & .445 & .75375889 \\
\hline
\end{tabular}

Berdasarkan perhitungan nilai R Square yang telah dihitung adalah sebagai berikut:

$\mathrm{X} 2=(\mathrm{n}-1) * \mathrm{R}$ Square

$\mathrm{X} 2=(11-1) * 0.509$

$\mathrm{X} 2=5.090$

Dan nilai X2 tabel pada chi square sebesar (19.6751)

Dari tabel nilai X2 hitung dan ketentuan tabel chi square df.(k,taraf signifikansi $(\alpha 0,05)$ didapat nilai X2 hitung (5.090) < X2 tabel (19.6751) sehingga dapat diambil kesimpulan bahwasanya model persamaan atas regresi dalam penelitian ini tidak lagi mengandung gejala autokorelasi. 
5. Regresi Linier Berganda

Tabel 4. Regresi Linier Berganda

\begin{tabular}{lrrrrr}
\multicolumn{7}{c}{ Coefficients $^{\mathbf{a}}$} \\
\hline \multicolumn{7}{c}{$\begin{array}{c}\text { Unstandardized } \\
\text { Coefficients }\end{array}$} & $\begin{array}{c}\text { Standardized } \\
\text { Coefficients } \\
\text { Model }\end{array}$ & \multicolumn{1}{c}{ B } & Std. Error & t & Sig. \\
\hline 1 (Constant) & 4.706 & .574 & & 8.198 & .000 \\
Likuiditas $\left(X_{1}\right)$ & -.579 & .310 & -.409 & -1.866 & .068 \\
Aktivitas $\left(X_{2}\right)$ & .635 & .280 & .295 & 2.266 & .028 \\
Profitabilitas $\left(X_{3}\right)$ & .343 & .176 & .247 & 1.952 & .046 \\
Solvabilitas $\left(X_{4}\right)$ & -.323 & .246 & -.292 & -1.311 & .196 \\
\hline
\end{tabular}

a. DependentVariable:Harga Saham

Sumber: Peneliti (2021)

Dari tabel diatas dapat dijelaskan bahwa :

1. Nilai konstanta $(\alpha)$ sebesar 4.706 artinya apabila likuiditas, aktivitas, profitabilitas dan solvabilitas nilainya adalah 0 , maka harga saham nilainya akan naik sebesar 4.706 poin/rupiah.

2. Nilai koefisien regresi variabel likuiditas sebesar -.579 yang mengartikan bahwa jika variabel lainnya tetap dan likuiditas mengalami kenaikan sebesar 1 satuan maka harga saham dapat mengalami penurunan sebesar Rp. -0.579. Koefisien bernilai negatif yang beratri dapat disimpulkan ada hubungan negatif antara likuiditas dengan harga saham.

3. Nilai koefisien regresi variabel aktivitas sebesar .635 yang mengartikan bahwa jika variabel lainnya tetap dan aktivitas mengalami kenaikan sebesar 1 satuan maka harga saham dapat mengalami kenaikan sebesar Rp. 0.635. Koefisien bernilai positif yang berarti dapat disimpulkan ada hubungan positif antara aktivitas dengan harga saham.

4. Nilai koefisien regresi variabel profitabilitas sebesar .343 yang mengartikan bahwa jika variabel lainnya tetap dan profitabilitas mengalami kenaikan sebesar 1 satuan maka harga saham dapat mengalami kenaikan sebesar Rp. 0.343. Koefisien bernilai positif yang berarti dapat disimpulkan ada hubungan positif antara profitabilitas dengan harga saham.

5. Nilai koefisien regresi variabel solvabilitas sebesar -.323 yang mengartikan bahwa jika variabel lainnya tetap dan solvabilitas mengalami kenaikan sebesar 1 satuan maka harga saham dapat mengalami penurunan sebesar Rp. -0.323. Koefisien bernilai negatif yang berarti dapat disimpulkan ada hubungan negatif antara solvabilitas dengan harga saham.

6. Uji T (Parsial)

Tabel 4.1 Uji T (Parsial) Coefficients $^{\mathrm{a}}$

\begin{tabular}{|c|c|c|}
\hline Model & t & Sig. \\
\hline 1 (Constant) & 8.198 & .000 \\
\hline Likuiditas $\left(\mathrm{X}_{1}\right)$ & -1.866 & .068 \\
\hline Aktivitas $\left(\mathrm{X}_{2}\right)$ & 2.266 & .028 \\
\hline Profitabilitas $\left(\mathrm{X}_{3}\right)$ & 1.952 & .046 \\
\hline Solvabilitas $\left(\mathrm{X}_{4}\right)$ & -1.311 & .196 \\
\hline
\end{tabular}

Sumber : Peneliti (2021)

T tabel dalam penelitian ini sebesar:

$\mathrm{t}$ tabel $=(0.05 / 2 ; 55-4-1$ atau $\mathrm{df}$ nilai residual $)$

$\mathrm{t}$ tabel $=1.67591$ 
Dari perhitungan nilai t-tabel dan hasil outpun perhintungan dan nilai t-hitung dapat dijelaskan sebagai berikut :

1. Hasil pengujian secara parsial (uji-t) Likuiditas terhadap harga saham didapat nilai $t-$ hitung dan t-tabel sebesar $-1.866<1.67591$ dan untuk probabilitas signifikansi sebesar $0.068>0.05$.

2. Hasil pengujian secara parsial (uji-t) Aktivitas terhadap harga saham didapat nilai thitung dan t-tabel sebesar $2.266>1.67591$ dan untuk probabilitas signifikansi sebesar $0.028<0.05$.

3. Hasil pengujian secara parsial (uji-t) Profitabilitas terhadap harga saham didapat nilai hitung dan t-tabel sebesar $1.952>1.67591$ dan untuk probabilitas signifikansi sebesar $0.046<0.05$.

4. Hasil pengujian secara parsial (uji-t) Solvabilitas terhadap harga saham didapat nilai thitung dan t-tabel sebesar $-1.311<1.67591$ dan untuk probabilitas signifikansi sebesar $0.196>0.05$.

7. Uji F Simultan

Tabel 4.2 Uji F (Simultan)

\begin{tabular}{llrrrrr}
\multicolumn{7}{c}{ ANOVA $^{\mathrm{a}}$} \\
\hline Model & & Sum of Squares & df & Mean Square & F & Sig. \\
\hline 1 & Regression & 14.010 & 4 & 3.502 & 3.218 & $.020^{\circ}$ \\
& Residual & 54.417 & 50 & 1.088 & & \\
& Total & 68.426 & 54 & & & \\
\hline
\end{tabular}

a. DependentVariable: Harga Saham

b. Predictors: (Constant), Solvabilitas, Profitabilitas, Aktivitas, Likuiditas

Sumber : Peneliti (2021)

Nilai F tablel:

$\mathrm{df} 1=4-1$

$\mathrm{df} 2=50-4$

sehingga (df1 $=3 ;$ df2 46)

sehingga $F$ tabel sebear 2.806

Dari tabel hasil pengujian $\mathrm{F}$ dapat diambil keputusan bahwasanya nilai $\mathrm{F}$ hitung sebesar $3.218>2.806$ dari $\mathrm{F}$ tabel dan nilai signifikansi sebesar $0,020<$ dari $0,05(\alpha)$.

8. Koefisien Determinasi

Tabel 4.3 Koefisien Determinasi

Model Summary

\begin{tabular}{lcrrr}
\hline Model & $\mathrm{R}$ & R Square & $\begin{array}{c}\text { Adjusted R } \\
\text { Square }\end{array}$ & $\begin{array}{c}\text { Std. Error of the } \\
\text { Estimate }\end{array}$ \\
\hline 1 & \multicolumn{7}{c}{ S14 } & .509 & .445 & .75375889 \\
\hline a. & Predictors: (Constant), UT_2, Likuiditas, Profitabilitas, Aktivitas, \\
& UT_1, Solvabilitas \\
& Sumber: Peneliti (2021)
\end{tabular}

Dari tabel diatas dapat dijelaskan bahwa dengan hasil R Square bernilai 0.509 atau 50.9 $\%$ yang mengandung pengertian bahwa seluruh variabel berpengaruh sebesar 50.9\%. sementara sisanya sebesar $(100 \%-50.9 \%=49.1)$ dipengaruhi oleh variabel lain selain dari variabel yang ada dalam penelitian tersebut,dengan hasil penelitian yang dilakukan oleh (Idamanti, 2018). 


\section{SIMPULAN}

\section{Pengaruh Likuiditas Terhadap Harga Saham}

Likuiditas (X1) terhadap harga saham (Y) didapat nilai t-hitung dan t-tabel sebesar -1.866 < 1.67591 dan untuk probabilitas signifikansi sebesar $0.068>0.05$. Sehingga dengan demikian dapat diambil kesimpulan rasio likuiditas (X1) tidak berpengaruh terhadap harga saham. Penelitian tersebut memiliki hasil yang berbeda dengan penelitian yang dilakukan oleh (Idamanti, 2018).

\section{Pengaruh Aktivitas Terhadap Harga Saham}

Aktivitas (X2) terhadap harga saham (Y) didapat nilai t-hitung dan t-tabel sebesar 2.266 > 1.67591 dan untuk probabilitas signifikansi sebesar $0.028<0.05$. Sehingga dengan demikian dapat diambil kesimpulan rasio Aktivitas (X2) berpengaruh terhadap harga saham. Hasil penelitian tersebut sejalan dengan penelitian yang dilakukan oleh (Aviliankara \& Sarumpaet, 2017).

\section{Pengaruh Profitabilitas Terhadap Harga Saham}

Profitabilitas (X3) terhadap harga saham (Y) didapat nilai t-hitung dan t-tabel sebesar 1.952 $>1.67591$ dan untuk probabilitas signifikansi sebesar $0.046<0.05$. Sehingga dengan demikian dapat diambil kesimpulan rasio Profitabilitas (X3) berpengaruh terhadap harga saham. Hasil penelitian tersebut sama dengan hasil penelitian yang dilakukan oleh (Anita Suwandani, Suhendro, 2017).

\section{Pengaruh Solvabilitas Terhadap Harga Saham}

Solvabilitas (X4) terhadap harga saham (Y) didapat nilai t-hitung dan t-tabel sebesar -1.311 $<1.67591$ dan untuk probabilitas signifikansi sebesar $0.196>0.05$. Sehingga dengan demikian dapat diambil kesimpulan rasio Solvabilitas (X4) tidak berpengaruh terhadap harga saham. Hasil penelitian tersebut menunjukkan hasil yang sama dengan penelitian (Octaviani \& Komalasarai, 2017).

5. Pengaruh Likuiditas, Aktivitas, Profitabilitas dan Solvabilitas Terhadap Harga Saham Hasil pengujian F dapat diambil keputusan bahwasanya nilai F hitung sebesar 3.218 $>2.806$ dari $\mathrm{F}$ tabel dan nilai signifikansi sebesar $0,020<$ dari $0,05(\alpha)$ maka, Likuiditas, Aktivitas, Profitabilitas, Solvabilitas berpengaruh terhadap harga saham.

\section{SARAN}

1. Peneliti selanjutnya diharapkan menambahkan variabel lain seperti dividen atau pun EPS sebab kedua variabel tersebut dapat menguntungkan investor juga.

2. Bagi investor yang telah berinvestasi dipasar modal terutama pada saham sektor transportasi dan logistik dapat memperhatikan rasio analisis keuangan perusahan terutama pada rasio likuiditas dan profitabilitas sebab kedua rasio tersebut memiliki pengaruh terhadap harga sahamnya.

3. Bagi perusahaan yang akan meningkatkan modalnya melalui penjualan saham dipasar modal diharapkan dapat lebih meningkatkan lagi kinerja keuangannya sehingga imvestor tertarik dan menempatkan dananya pada perusahaan.

\section{DAFTAR PUSTAKA}

Aviliankara, D. M., \& Sarumpaet, T. L. (2017). PENGARUH RASIO LIKUIDITAS, RASIO SOLVABILITAS, RASIO AKTIVITAS, DAN RASIO PROFITABILITAS TERHADAP HARGA SAHAM (Studi Empiris pada Perusahaan Manufaktur Sektor Barang Konsumsi yang Terdaftar di Bursa Efek Indonesia Periode 2013-2015). Profesionalisme Akuntan Menuju Sustainable Business Practice. Bandung: Universitas Widyatama.

Idamanti, N. (2018). Pengaruh Likuiditas, Profitabilitas Dan Penjualan Terhadap Harga Saham Perusahaan Makanan Dan Minuman Yang Tercatat Di Bursa Efek Indonesia Tahun 20102014. Manajemen Bisnis, 6(2), 118-127. https://doi.org/10.22219/jmb.v6i2.5538

Kasmir. (2016). Pengantar Manajemen Keuangan. Jakarta: Kencana Prenada Media Grup.

Nisa, H. (2018). PENGARUH RASIO KEUANGAN TERHADAP HARGA SAHAM PADA 
INDUSTRI SEKTOR PERTANIAN YANG TERDAFTAR DI BURSA EFEK INDONESIA TAHUN 2012-2016. UNIVERSITAS NEGERI YOGYAKARTA.

Octaviani, S., \& Komalasarai, D. (2017). PENGARUH LIKUIDITAS, PROFITABILITAS, dan SOLVABILITAS TERHADAP HARGA SAHAM (Studi Kasus pada Perusahaan Perbankan yang Terdaftar di Bursa Efek Indonesia). Jurnal Akuntansi., 3(2), 77-89.

Sudana, I. M. (2011). Manajemen Keuangan Perusahaan Teori dan Praktek. Jakarta: Erlangga. Syahyunan. (2015). Manajemen Keuangan (Perencanaan, Analisis dan Pengendalian Keuangan (2nd ed.). Medan: USU Press. 